\title{
Film Production Incentives, Employment Transformation and \\ Domestic Expenditure in South Africa: Visualizing Subsidy \\ Effectiveness
}

\author{
Alan Collins*, Alessio Ishizaka**, Jen Snowball*** \\ *Portsmouth Business School, University of Portsmouth, Portsmouth, UK and Hobart \\ Houghton Research Fellow, Department of Economics and Economic History, Rhodes \\ University; ** Portsmouth Business School, University of Portsmouth, Portsmouth, UK; \\ ***Department of Economics and Economic History, Rhodes University, \\ Grahamstown, South Africa.
}

\author{
Alan Collins \\ Hobart Houghton Research Fellow \\ Department of Economics and Economic History \\ Rhodes University \\ PO Box 94 \\ Grahamstown 6140, South Africa \\ and \\ Economics and Finance Group \\ Portsmouth Business School \\ University of Portsmouth \\ Portsmouth, PO1 3DE, UK \\ Email: alan.collins@ port.ac.uk \\ Telephone: +44 2392844128 \\ Fax: +44 2392844037
}

\author{
Alessio Ishizaka \\ Portsmouth Business School \\ University of Portsmouth \\ Portsmouth, PO1 3DE, UK \\ Email: alessio.ishizaka@port.ac.uk
}

\section{Jen Snowball (CORRESPONDING AUTHOR)}

Department of Economics and Economic History

Rhodes University

PO Box 94

Grahamstown 6140

South Africa

Email: j.snowball@ru.ac.za

Telephone: +27 466037405

Fax: +27 466225120 


\title{
Film Production Incentives, Employment Transformation and \\ Domestic Expenditure in South Africa: Visualizing Subsidy Effectiveness
}

\begin{abstract}
In 2004 the South African Department of Trade and Industry (DTI) introduced a Film and Television Production Rebate Programme. In order to qualify for the rebate, certain criteria have to be met including success in job creation and skills development within the industry, alongside a particular focus on the percentage of "historically disadvantaged individuals" (HDIs) employed. This study sets out the issues associated with evaluating success in meeting these various criteria and is, to the best of our knowledge, the first study to apply multi-criteria visualization techniques to inform the evaluation of public subsidy effectiveness. The 'PROMETHEE' method is applied and apart from presenting project performance in a visually intuitive manner, the approach helps to clarify patterns of relative success, show where policy objectives are competing, and to identify project exemplars for more efficiently guiding future public support in the sector.
\end{abstract}

Keywords: words: subsidy effectiveness, employment, film industry, transformation, South Africa

\section{Introduction}

The risky nature of creative production, and the "mystique" surrounding creative outputs, make the cultural and creative industries (CCIs) an interesting case study in the field of arts management and policy (Lampel and Germain, 2015). The risk associated with CCI production, particularly in the film and television sectors, has consequences: On the production side, the difficulty of attracting investment finance, and typically short-term nature of project-based employment opportunities (Vincenti and Boccardelli, 2015); on the consumption side, the difficulty of predicting demand and subsequent revenue generation (Gazley, 2011).

CCIs also generate values that extend far beyond the provision of leisure and entertainment "goods": they can also be important in creating cultural capital, in identity 
formation, and in building social cohesion. As Gkritzali and Weirtz (2015) show in their study of the role of Hollywood films in the image creation of locations like Paris, the CCIs can also be "place makers". Through them popular conceptions of national characteristics can be developed, with the resultant impacts on tourism, trade and even diplomacy.

It is because of all these non-market, public good values, as well as the employment and economic growth potential of the CCIs themselves, that governments often subsidise them. Yet subsidies can create multiple, sometimes competing, incentives both for governments, attempting to find ways of evaluating the effectiveness of spending on the CCIs, and for CCIs themselves, as originally pointed out by Caves (2000). This is particularly the case in the film and television industry in South Africa, where the Department of Trade and Industry (who control the largest subsidies) focus on the growth and employment creation potential of the industry, while the National Film and Video Foundation, who have smaller resources, are more interested in nonmarket outcomes, such as the creation of cultural capital and national identity.

Establishing the worth of public financial support for various industrial sectors, but especially the creative industries sector, has thus proved a source of contention and debate among arts professionals, government and economists. A broadly accessible means of presenting the issues to all parties in an intuitive way would seem to be warranted and this task forms the focus of the study presented herein.

Various issues and literatures on film subsidy effectiveness have recently been outlined and explored in the context of three very different national film (and in one case also television) industries. These are set out in MacKenzie and Walls (2013) for Australia; Teti, Collins and Sedgwick (2014) for Italy and Collins and Snowball (2015) for South Africa. Evaluating the effectiveness of subsidy is also rendered more 
problematic when there is (i) a desire for such subsidies to achieve multiple and possibly conflicting policy objectives and (ii) there are two or more governmental agencies favouring different objectives (e.g. economic development, employment enhancement, cultural prestige building). These features beset consideration of many national film industries.

This particular study does not rehearse again the well-trodden arguments regarding the general merits and demerits of public financial support for the arts, which are outlined in the film subsidy studies previously cited. Rather, it illustrates a specific practical means of evaluating subsidy effectiveness (previously used in, for example, the work of Ghazinoory et al, 2013 and, for a survey of other applications, Behzadian et $a l, 2010)$. The paper is organized as follows. The next section sets out the policy and country context in South Africa. The data and research method are then set out, after which results are presented and discussed, with concluding remarks offered in the final section.

\section{The South African Film Industry}

Despite nearly 20 years of democracy, South Africa remains a country divided largely along racial lines, with one of the highest Gini coefficients in the world (United Nations Human Development Report, 2011). This is also reflected in the film and television industry, particularly in terms of the content of South African productions (Botha 2003). Early exposure to high technology, US productions has given South African audiences a taste for technically sophisticated international films and television productions, with which many local producers find it difficult to compete (Creative Industries Report, 2008). Unlike the Nigerian film industry ("Nollywood"), South African films made by South Africans, about South Africans, have seldom managed even to cover their costs (Barnard and Tuomi, 2008; NFVF, 2008; NFVF, 2011). 
Nevertheless, the South African film and television industry, centred mostly on the cities of Cape Town and Johannesburg, has grown significantly in the past 20 years (Creative Industries Report, 2008; NFVF, 2013). Existing skills and knowledge, advanced technical capacity, a great variety of locations, and competitive prices have all encouraged the production of foreign film and television series (Tuomi, 2007). Not only can such projects provide valuable foreign exchange inflow, but they are also an opportunity for skills transfer, further developing the capacity and competitiveness of South African labour in the industry.

A dichotomy thus exists: on the one hand, the film and television industry has been very successful in building technical capacity and attracting large budget international productions; but on the other, local productions are struggling to source financing and attract audiences. There have been some notable exceptions, such as "Tsotsi", and "Otello Burning", which were box office successes both in South Africa and internationally, but these have tended to be in the minority. The Creative Industries Report (2007:19) said of the South African film sector: "With more that $90 \%$ of all film releases in South Africa consisting of imported material there is no doubt that local talent and local content remains a priority". They attribute the lack of local content to poor distribution and marketing channels, both locally and internationally, but also to the small size of the domestic market, and lack of audience development programmes. Flanery (2009) also points out that the lack of exhibition venues in black townships means that even films intended primarily for black audiences often fail to reach them.

Like all cultural industries, film and television can provide both market and nonmarket benefits (Towse, 2011). Market benefits, such as job creation, foreign exchange inflow, investment, increases in GDP and so on, are more easily measurable, and thus tend to be the focus of creative industry reports and strategies. However, non-market 
benefits, such as fostering social cohesion, an appreciation of other points of view, an examination of identity, and being the source of a sense of pride, can be equally important (Creative Industries Report 2007, Townley et al., 2009), especially in a country like South Africa, still struggling to come to terms with its apartheid past. In this sense, the film and television sector can be said to provide a public good that should be supported by the government.

Recognising both the potential market and non-market benefits, many countries have supported their film and television industry in some way, most usually through a subsidy or tax rebate scheme (Creative Industries Report, 2007; Kettering, 2012). Film and television production in apartheid South Africa maintained technical expertise, but produced content for a largely white audience and was heavily controlled and censored by the state (NFVF, 2000). The post-1994 government recognised the urgent need to diversify both the content and the skills base in the industry, as well as to encourage and maintain the competitiveness of foreign film production.

The first goal was addressed through the establishment of the National Film and Video Foundation (NFVF) in 1997, under the Department of Arts Culture Science and Technology. The primary mandate of the NFVF was to create an environment in which the South African film and video industry could develop, and to promote South African films locally and internationally (Botha 2003). The objectives of the NFVF are listed as: "to increase the number of SA films and PDIs [Previously Disadvantaged Individuals] producing them; to increase audience access to SA films; to increase the number of people trained in the industry, particularly in areas of shortage of skills; and to promote Social Cohesion and opportunities to express the nation's stories through film" (NFVF website, 2013). 
In 2004 the South African Department of Trade and Industry (DTI) introduced the Film and Television Production Rebate Programme, the main aim being to attract large-budget foreign productions to South Africa. In 2008, the programme was changed to include support for local film and television productions, as well as co-productions involving both South African and foreign partners (DTI, 2008a; 2008b). In 2011/12, rebates for post-production activities were also included (DTI, 2011; 2012).

In order to qualify for the rebate, certain criteria have to be met by all three categories (that is, South African productions; Co-productions; and Foreign productions). For South African productions and Co-productions, South Africans must be the majority share-holders in the legal entity (Special Purpose Vehicle) established for the project, and at least one South African must play an active role in the production. There is a minimum spending requirement of $\mathrm{R} 2.5$ million, on which a rebate of $35 \%$ can be claimed for the first R6 million, and 25\% thereafter.

For foreign projects, there is a minimum spending requirement of R12 million, with at least $50 \%$ of principal photography to take place in South Africa, and a minimum of 4 weeks of filming. Including the post-production incentive, such projects can claim between $22.5 \%$ and $25 \%$ of Qualifying South African Production Expenditure (QSAPE).

All projects must comply with Broad-Based Black Economic Empowerment (BBBEE) employment practices, which focus on addressing past imbalances by transforming the ownership and skills profiles of South African firms to more closely represent the demographics of the country (B-BBEE Act 2003). Compliance with certain quotas for the employment of black South Africans, and reporting according to the B-BBEE scorecard (Codes of Good Practice on B-BBEE 2007) are required in order for any project to be eligible for the DTI rebate scheme. 
After the data period for which this research was conducted, a new sub-category of the DTI incentives of South African productions and co-productions was introduced: The South African Emerging Black Filmmakers Incentive Scheme (DTI, 2014). The purpose of this new category, very much in line with the recommendations of Collins and Snowball (2014), was specifically focused on the production of local content by black South Africans in order to develop skills and create jobs for this specific group of people. The subsidy was at a much higher rate than the other categories $(50 \%$ of QSAPE), with a lower qualifying spending requirement (R1 million) and the requirement that at least $75 \%$ of SPV owners should be black South Africans, who must play active, credited production roles. The new sub-category was a clear attempt to address the fact that, while the subsidy scheme was successful in boosting spending for bigger productions and, to some extent, creating jobs and developing skills, it was excluding smaller productions by local film producers.

An (August 2012) industry report to the DTI on the impact of the incentive schemes (including input from the Independent Producers Organization, the Documentary Filmmakers Association, and the South African Screen Federation), emphasised the job creation and skills development of the industry, with a particular focus on the percentage of "historically disadvantaged individuals" (HDIs) employed. However, a recommendation of the report was that changes to the co-production rebate put forward by the NFVF (which would require more South African ownership and direct participation to qualify) should be carefully considered:

"We fear that the current proposed changes are in contravention of international treaties and would result in massive job losses and decimation of the South African co-production sector worth R1.285 billion over the last four years" (Industry Report, 2012:11). 
This is a clear demonstration that, while there is significant potential overlap between goals of the NFVF and the DTI, there are also tensions, particularly in a country with a $25 \%$ unemployment rate, where economic growth and job creation are of paramount importance (Quarterly Labour Force Survey, 2013).

There is some evidence, however, that the South African film and television industry has become more, rather than less, concentrated. Vazquez-Maguirre and Hartmann (2013) find a similar structure in their study of the Mexican television industry, where they show how firms with first-mover advantages can use non-market strategies to enhance and maintain their dominant market positions. The report commissioned in 2000 by the NFVF in South Africa identified a trend of "increasing consolidation" in the industry. While this enabled some firms to gain from economies of scale and to become increasingly successful in bidding for large, international productions, it was perhaps an indicator that diversification (of ownership and content) was an unlikely outcome. This is also likely to be reflected in terms of subsidy concentration. Collins and Snowball (2015) showed that, between 2009 and 2011, nearly three-quarters (73\%) of DTI rebates were paid to just ten firms.

They also found that subsidised film and television projects (between 2009 and 2011) contributed an average of R2.2 billion to South Africa's GDP. They calculated that subsidised projects created approximately 5700 full time equivalent (FTE) direct, and a further 10000 FTE indirect, jobs per year. A study of the whole South African film and television industry in 2012 (NFVF 2013) found that it contributed R3.5 billion to GDP and created just over 25000 FTE jobs. Both studies conclude that the return on the subsidy is thus good (in term of both GDP and tax revenues generated) and that there is clear evidence that the film and television industry is an important component of the economy, even taking into account only the market benefits. 


\section{Data}

Subsidy claim data was provided by the South African Department of Trade and Industry (DTI) for the period 2009 to June 2012. Analysis was sanctioned only on completed projects and where no identification of individual project costs was permitted, as this might afford contemporary commercial intelligence to competing firms. The data set contained information on the date of application approval, the Qualifying South African Production Expenditure (QSAPE), and employment in various categories, divided into white and black people. QSAPE refers to production expenditure by the applicant on goods, facilities and services provided by South African companies, which could also include copyrights. Non-qualifying expenditures include items such as financing expenditure, general business overheads and physical capital (such as land and buildings, depreciation and the cost of services embodied in goods).

The raw project employment data did not reflect typical film/TV project durations, and the problem of multiple counting of full-time jobs was evident in the data. Accordingly, the employment data was weighted to convert project jobs in various employment categories (producers, "creatives", crew, cast and extras) to annual FullTime Equivalent (FTE) jobs. The values of these weights were informed by project approval and claim dates, internal industry sourced publications and a number of elite interviews with senior executives from film production companies and the Western Cape Film Board.

Analysis is made of three full years of 2009-2011 of authorized incentive claims for 106 film and television projects over this period. However, only 69 of the 106 film projects were completed at the time of the analysis. The financial data was deflated using the South African Consumer Price Index $(2008=100)$. The summary statistics for the raw data used are given in Table 1 to present the broad dimensions of the 
spending in South African rand (QSAPE), foreign investment (yes/no) by CoProduction and various categories of employment. For the subsequent PROMETHEE analysis the values in Table 1 were then divided by the amount of project subsidy they received to enable meaningful comparative analysis of subsidy effectiveness among the various performance metrics (spending in South Africa, co-production, employment type). Interestingly, the median values for all the employment variables were zero, indicating in many cases no employment impacts, or, for whatever commercial reasoning, deliberately incomplete subsidy claims.

Table 1: Summary Statistics

\begin{tabular}{|c|c|c|c|c|c|}
\hline & $\begin{array}{l}\text { Qualifying } \\
\text { South } \\
\text { African } \\
\text { Production } \\
\text { Expenditure } \\
\text { (in South } \\
\text { African } \\
\text { Rand) }\end{array}$ & $\begin{array}{l}\text { Co- } \\
\text { Production } \\
\text { Projects }\end{array}$ & $\begin{array}{l}\text { Total } \\
\text { employment }\end{array}$ & $\begin{array}{l}\text { Total black } \\
\text { employment }\end{array}$ & $\begin{array}{l}\text { Skilled black } \\
\text { employment }\end{array}$ \\
\hline Mean & 8633546 & 0.014493 & 78.35 & 42.62 & 16.23 \\
\hline $\begin{array}{l}\text { Standard } \\
\text { deviation }\end{array}$ & 8870130 & 0.120386 & 124.51 & 86.80 & 38.23 \\
\hline median & 5605748 & 0 & 0 & 0 & 0 \\
\hline $\begin{array}{l}\text { Minimum } \\
\text { value }\end{array}$ & 2225028 & 0 & 0 & 0 & 0 \\
\hline $\begin{array}{l}\text { Maximum } \\
\text { value }\end{array}$ & 47069011 & 1 & 529.00 & 364.00 & 289.00 \\
\hline Range & 44843983 & 1 & 529.00 & 364.00 & 289.00 \\
\hline
\end{tabular}




\section{The Mode of Analysis}

\subsection{Preference Ranking Organization METHod for the Enrichment of Evaluations}

(PROMETHEE)

The analytical technique deployed is PROMETHEE (Brans and Vincke, 1985; Brans 1982) - a multicriteria method that requires only a few parameters and is easy to use and explain via non-technical user-friendly visualization software that is readily available (Gilliams et al, 2005). The evaluation of each criterion can be expressed in its natural units and therefore problems relating to scaling effects are completely eliminated. It thus has the advantage that a normalization of the scores is not required, which avoids the drawback that the ranking critically hinges on the selected normalization method (Ishizaka and Nemery, 2011; Tofallis, 2008). The decision-maker needs to define a preference function that is generally characterized only by an indifference and preference threshold. A more detailed description can be found in Ishizaka and Nemery (2011 and 2013), but the upshot is that a score is produced that is entirely relative to the pool of other projects. The score is relative and sums to 0 . This means that if we have, say, only two films and one has a score of 0.5 , then the second film will have a score of -0.5. In our study, PROMETHEE has been operationalised as following:

Problem definition: The performance of the set $F$ composed of sixty-nine films is evaluated on five criteria: QSAPE, Co-production, total employment, total black employment and skilled black employment.

Preference at criterion level: As we have several conflicting criteria, we first consider each criterion separately. All films are compared pairwise to one criterion at the time by subtracting their score on each criterion in a comparison matrix. For example, if total black employment of film $A$ is $14 \%$ and black employment of film $B$ is $10 \%$, the 
differences are $d(A, B)=4 \%$ and $d(B, A)=-4 \%$. The ensuing question is whether the difference, $d$, between these two cases is enough to say that one film is better than the other. To answer this question, a preference function, e.g. the linear function, is defined (Figure 1).

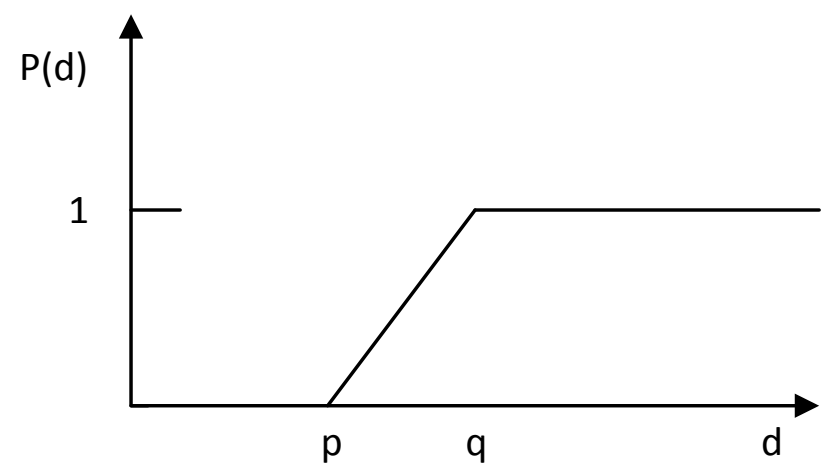

Figure 1: Linear preference function, $\mathrm{p}$ is the indifference threshold and $\mathrm{q}$ is the preference threshold

The preference degree $P(d(A, B))$ indicates how much film $\mathrm{A}$ is preferred over film $B$. It can vary between 0 and 1 . If $P(d(A, B))=0$, the difference $d$ between the two films on the criterion 'total black employment' is too small, and the two films are considered as indifferent. This is the case when the indifference threshold is $p \geq 4$ in Figure 1. In the case of $d(B, A)=-4 \%$, the preference degree is always 0 , as a film having a lower score cannot be better. If $\mathrm{q} \leq 4$, then the preference degree $P(A, B)=1$, i.e. film $A$ is clearly better than $B$. All other values between 0 and 1 indicate the intensity of preference of film $A$ over $B$.

Aggregated Preference Functions: Once all the pairwise comparisons on all criteria have been calculated and the preference degree determined, results show by how much film $A$ is preferred to $B$ over all the criteria. This preference index $\pi(A, B)$ is calculated with a weighted sum of the preference degrees $P(A, B)$. The weights, $w_{i}$, represent the 
importance of each of the criteria in the decision. In our case they are considered initially as equal.

$$
\pi(\mathrm{A}, \mathrm{B})=\sum_{i=1}^{n} P_{i}\left(d(A, B) \cdot w_{i}\right.
$$

where $P_{i}(d(A, B))$ is the score of the preference function, $w_{i}$ the weight of the criterion, $c_{i}$, and $n$, the number of criteria.

Outranking Flows: When all of the aggregated preference functions are calculated for each pair of films, the strength and weakness of each film can be defined. As each film is compared with 68 other films, two flows can be defined with:

The Positive flow:

(2) $\Phi^{+}(A)=\frac{1}{m-1} \sum_{x \in F}^{m} \pi(A, x)$

with $m$ being the number of films, i.e. 69 in our case

This score represents the global strength of film $A$ in comparison to all the other films. It is this score that has to be maximized.

The Negative flow:

(3) $\quad \Phi^{-}(A)=\frac{1}{m-1} \sum_{x \in F}^{m} \pi(x, A)$

with $m$ being the number of films of the set $F$.

This score represents the global weakness of $A$ in comparison to all the other films. It is this score that has to be minimized.

The complete ranking of PROMETHEE II is given by the net flow:

(4) $\quad \Phi(a)=\Phi^{+}(a)-\Phi^{-}(a)$ 
The higher the net flows, the better the rank of an action. A fuller discussion on net flow scores can be found in Brans and Mareschal (2005) and Mareschal et al. (2008).

\subsection{Visualizing the Results - Graphical Analysis for Interactive Aid (GAIA)}

Each criterion in multi-criteria decision making can be seen as a dimension. If we consider only two criteria, it is easy to visualize the position of each film, as shown graphically in Error! Reference source not found.

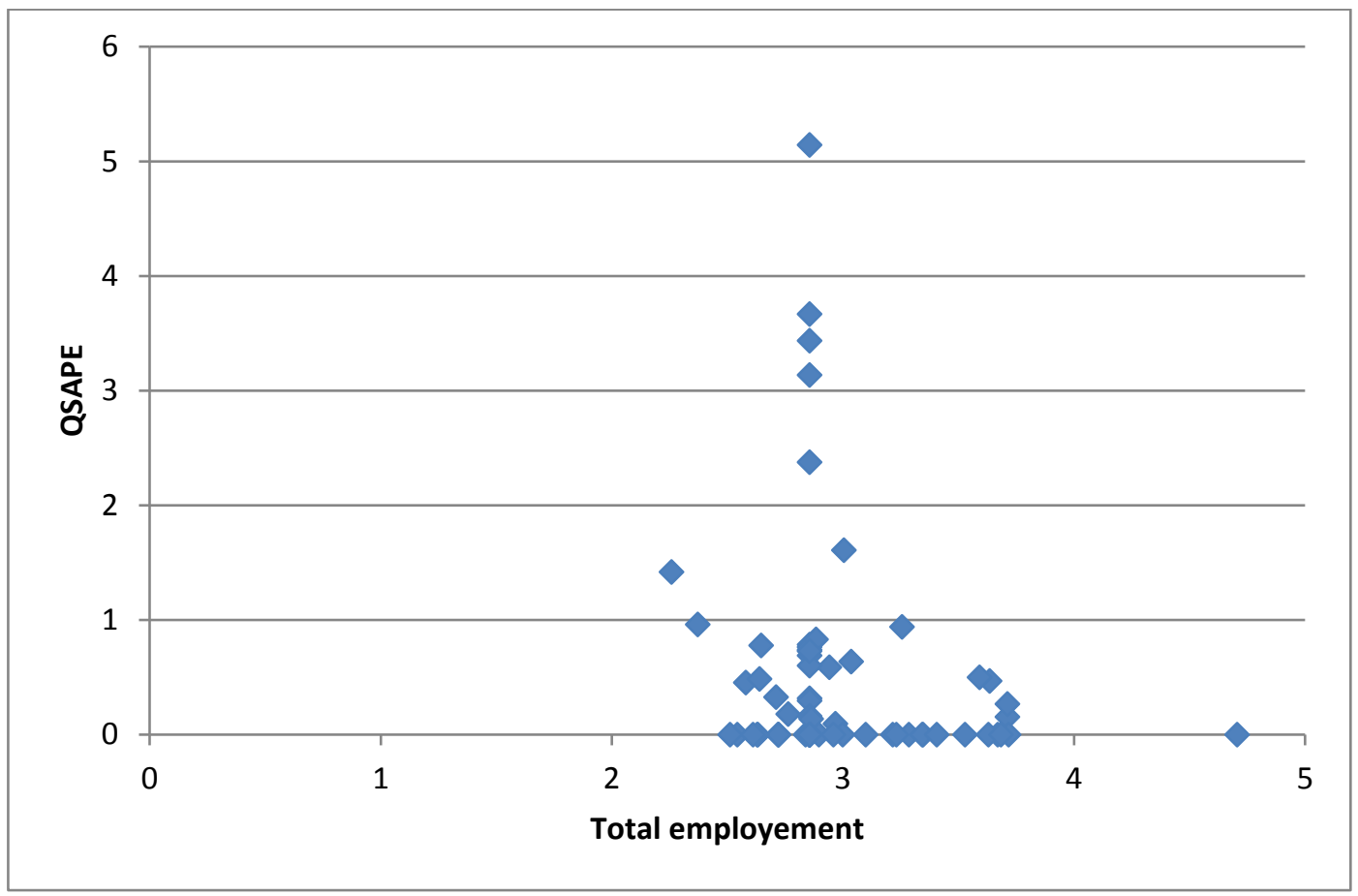

Figure 2: Visualization of two criteria of the film performance: Production spending and total employment creation.

The same visualisation for three criteria can be plotted in a three-dimensional space. However, the visualization becomes difficult for more than three dimensions. In the case of many criteria, we can use the dimensionality reduction technique of principal component analysis. In order to display the maximum information, we project the data onto a plane with the two axes having the maximal and next-to-maximal dispersions. 
These two axes correspond to the first two principal components. Error! Reference source not found. illustrates how a three dimensional space is projected onto the GAIA plan. The mathematical algorithm can be found in Brans and Mareschal (1994).

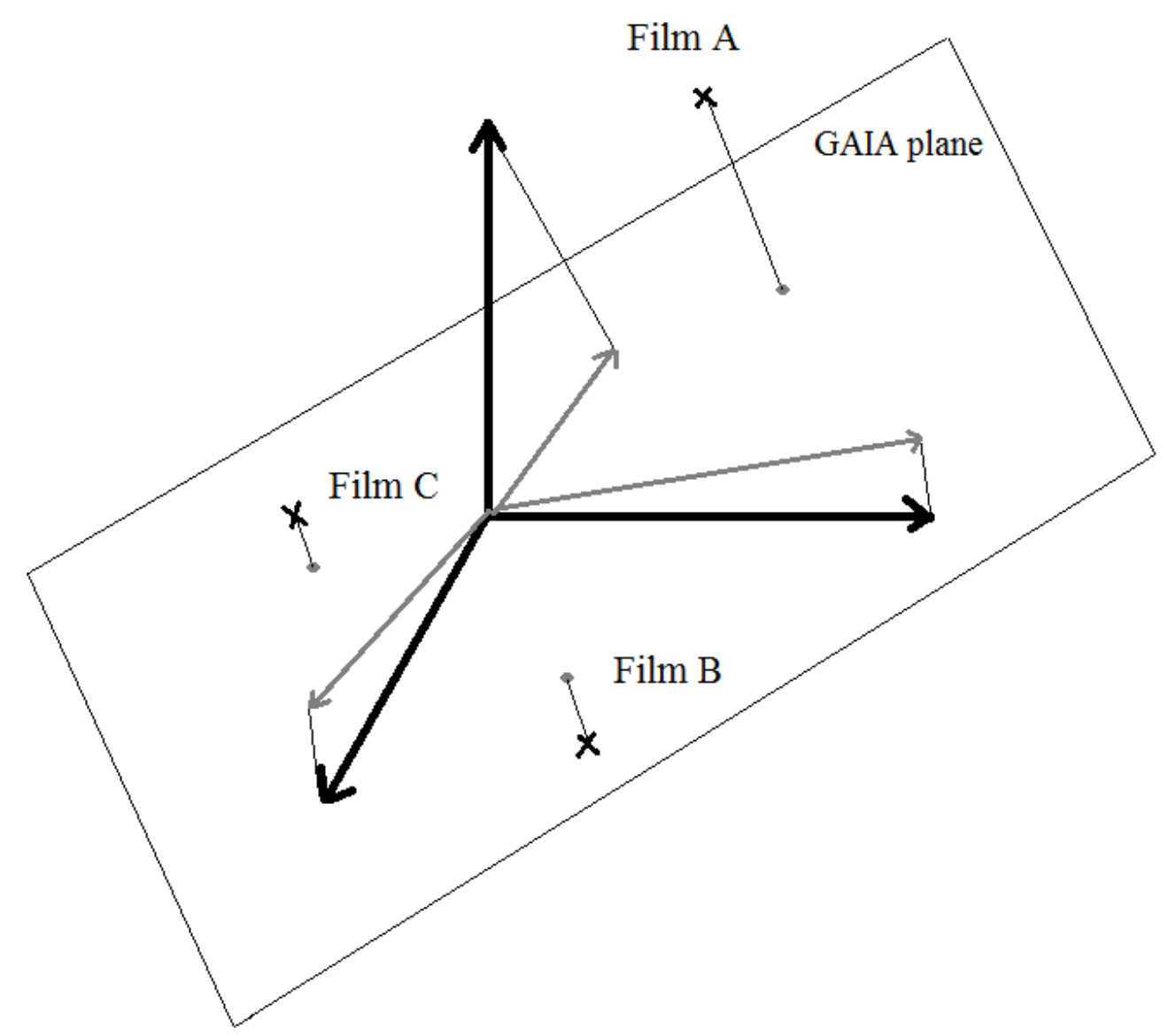

Figure 3: GAIA Plane Projection

\subsection{Interpreting the GAIA plane}

An illustrative example of a GAIA plane with more than two criteria is given in Error! Reference source not found., where the criteria represented by four vectors (see blue arrows emanating from centre) and the films are represented by dots. The decision line (labelled as DMG) represents the performance direction taking into account all criteria. 
The reading is done by projection on the relevant arrow. For example, film 3 is the best performing film overall, but on criterion 4 , film 1 is the best.

An angle between two vectors represent the degree of correlation between the two criteria, i.e. the smaller the angle between two arrows, the more correlated they are. For example, criterion 1 and 2 are closely correlated, but criterion 3 and 4 have an almost negative correlation. Finally, if films are close, it means that they have a similar levels of performance (e.g. film 2 and film 4).

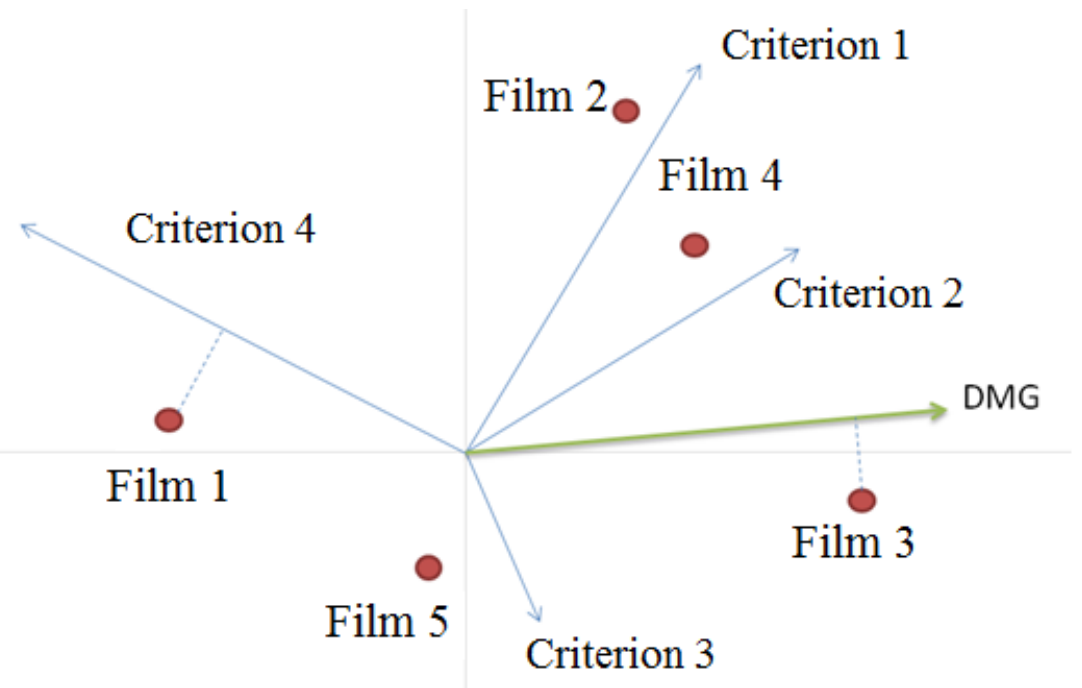

Figure 4: Example of the obtained AHP-GAIA graph

\section{Results and Discussion}

For the 3 years of data, comprising 69 formally completed projects (where subsidy has been paid, even though not all seem to have made all their potential employment claims), the data is very limited in terms of the international dimension. This could be considered an artefact of the data period as there have been many completed international and co-production projects in the preceding and subsequent time periods. However, their rarity in this 3-year period bears testimony to the uncertain and cyclical 
nature of these film project sources. Of the completed projects, the vast majority are domestic productions. QSAPE and the employment numbers have been converted to ratios by dividing through by the subsidy amount paid.

The performance targets are QSAPE itself (production spending in the South African economy), Co-productions (because of their potential for skills transfer), total employment, black employment, and total black skilled employment (i.e. minus extras). The latter 3 obviously co-move, but nonetheless feature points of interest. These pertain to certain key themes that group around score bandings.

Essentially from the base case analysis (Error! Reference source not found.) where all criteria are equally weighted we have three discernible categories:

1) Projects scoring low in all criteria, which are the majority of projects;

2) Projects scoring high in QSAPE and International co-production but scoring low on employment criteria (although it should be noted that we had only one case in this category); and

3) Projects scoring high in the employment criteria and scoring low in QSAPE and international co-production. 


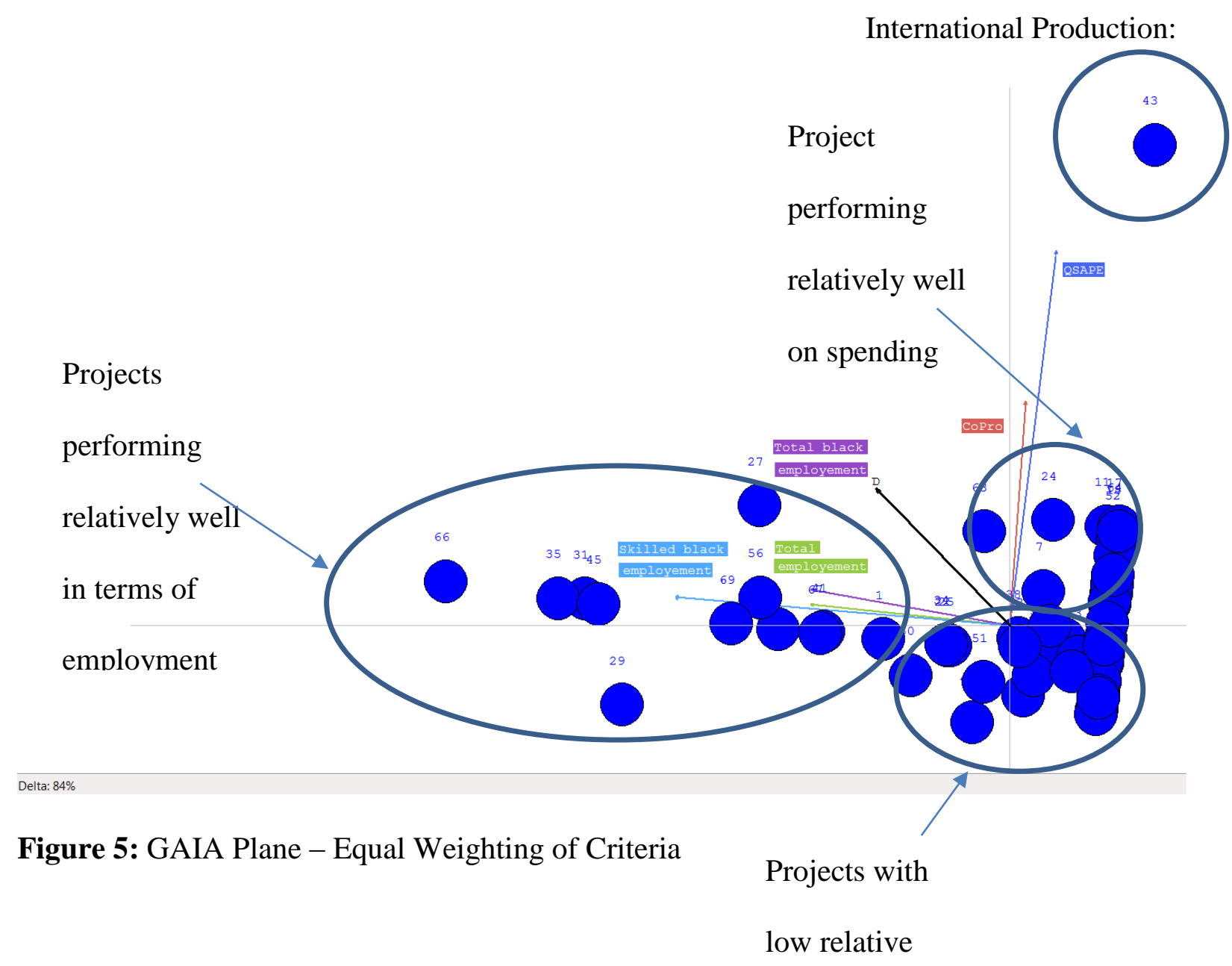

In terms of interpreting the results of Error! Reference source not found., the larger the angles between the variables, the higher the degree of potential policy tension between the desired outcomes. For example, QSAPE (spending) and Co-productions (that have the potential for skills transfer) are relatively close together, indicating that they are closely correlated and that there is no policy tension. Similarly, total employment, black employment and black skilled employment all move together. However, the angle between the Spending/Co-production variables and the Employment variables is large, indicating that there is significant policy tension between these aims. Funders may thus face a trade-off between these two groups of policy aims, since they are not mutually supportive. 
It is evident that, relative to other films in the data set, some do better in terms of QSAPE and black employment than others. They could thus be said to be fulfilling the objectives of the DTI (industry development and economic impact) and, to some extent, the NFVF (to increase the number of black people in the industry and to develop the skills base). The question remains, however, whether they are the "right" projects to subsidize in terms of the need to diversify content and to promote South African films both locally and internationally.

Analysis of the top 20 films in the list suggests that they are contributing to social and cultural debates and understanding in post-apartheid South Africa. The top three films are all comedies or romantic comedies set in South Africa and dealing with the challenges of living in a multicultural society. Two of the films are mostly in English, but incorporate other South African languages (with subtitles) as well. Although none of them was a great financial success or received great critical acclaim, they do deal with contemporary South African issues. Their contentious nature (examining such issues as inter-racial marriage, political issues, and differences in faith and culture) make them more likely to appeal to middle class audiences. Of the top 10 , only two (the one foreign film in the sample, and a nature documentary) were not about contemporary South African or African life. Four of the films were serious dramas about such issues as struggles with poverty, homophobia and the drug trade. However, while the top 20 films represent a mix of different languages, four of the top 20 films are in Afrikaans - still a disproportionately large number given that only $13.5 \%$ of South Africans speak Afrikaans (SA Census 2011).

Scores below 0.1 comprise the majority of the projects - suggesting that what the subsidy is effectively doing is to support some temporary project jobs, frankly, little else in terms of economic development. Error! Reference source not found. depicts 
these scores in a GAIA plane format and clearly shows this score band grouping and the discriminating criteria. The individual contribution to the scores for each project is set out in Error! Reference source not found. in a stacked bar chart.

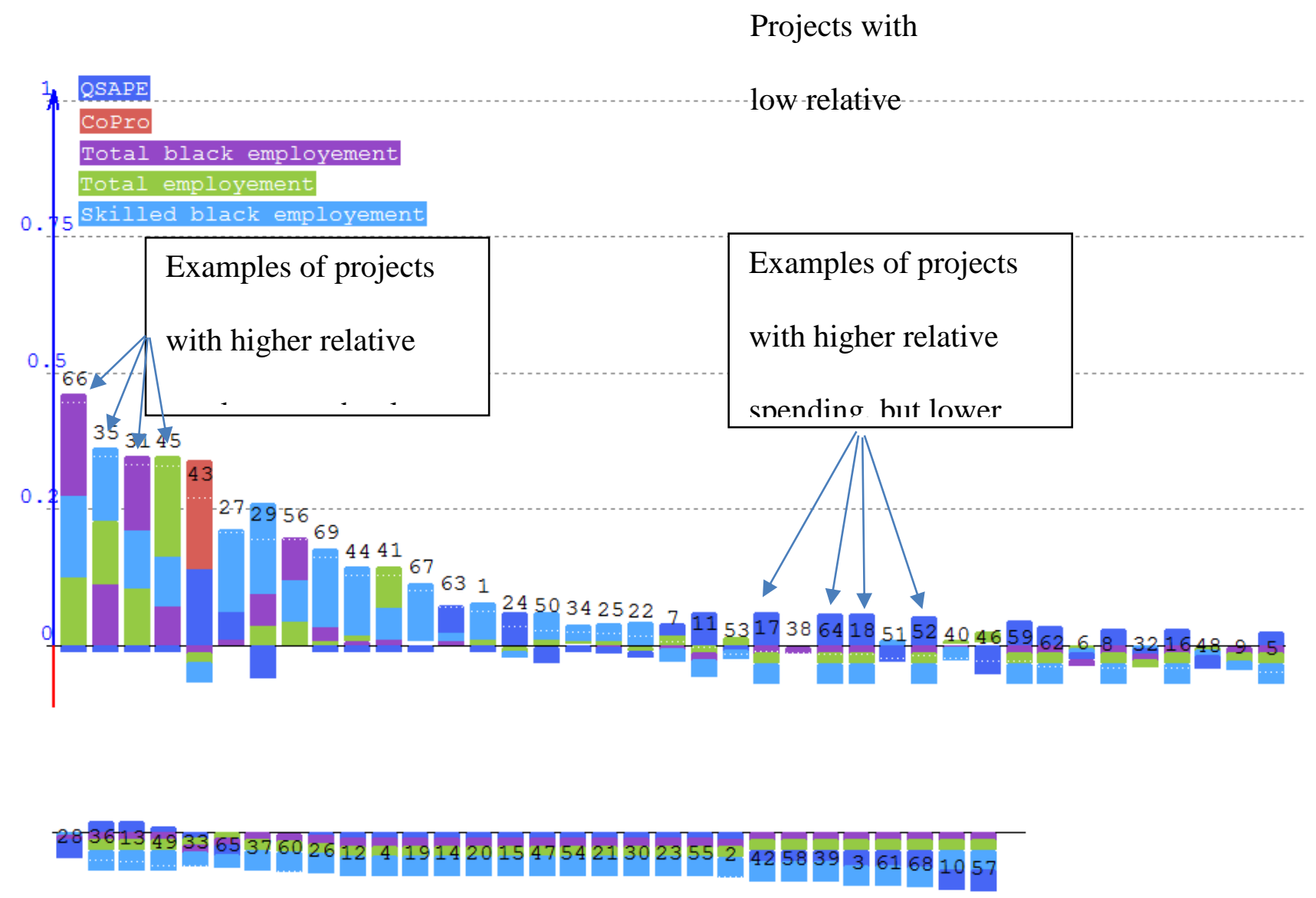

Figure 6: Project Scores and Individual Criteria Contribution

It is also possible to change the weightings of the variables in terms of their importance. However, despite double and quadruple weighting of the employment and black employment criteria, there was little change to the essential nature of the threefold score band categorization of the initial base run featuring equal criteria weighting. 


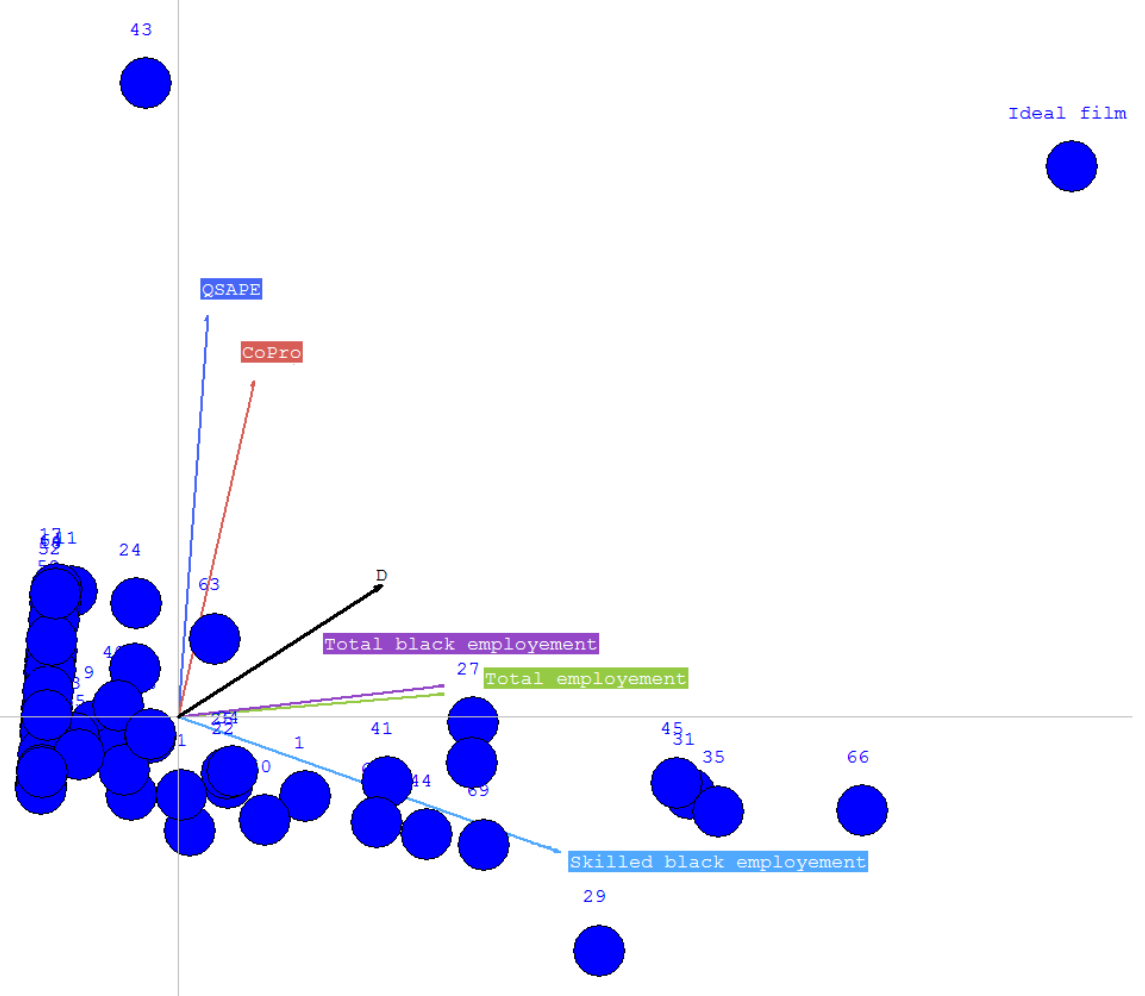

Delta: $86 \%$

Figure 7: GAIA Plane with 'Ideal' Film Benchmark

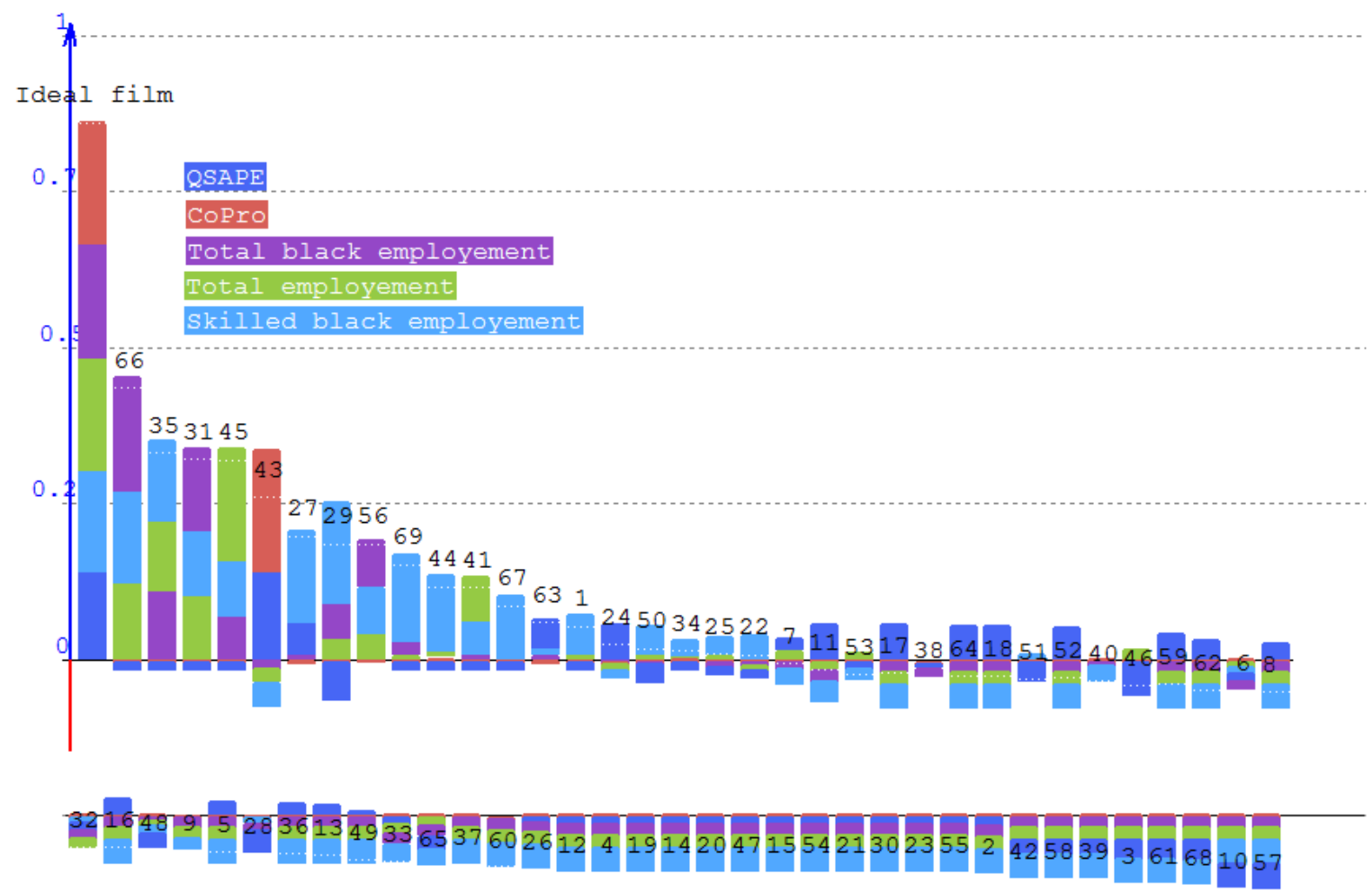

Figure 8: Project Scores with Individual Criteria Contribution - With 'Ideal' Film Project Benchmark 
Error! Reference source not found. and Error! Reference source not found. demonstrate the potential of this multi-criteria and visualization method for modelling performance against a desired combination of project criteria. Essentially a synthetic or fictional project is introduced into the analysis against which real project outcomes can be compared. The benchmark project features the real top scores on each criterion drawn from actual projects within the data. As can be seen from relative isolation visually there is considerable distance between it and the real projects. This again indicates that there exists considerable policy tension among any partisan advocates of these objectives in the contemporary South African context. What can also be seen is an emerging tension between total employment and black employment on the one hand, and skilled black employment on the other. This suggests that, although projects are meeting black economic empowerment quotas in order to qualify for the subsidy, there are still only a few projects where black people are employed in positions other than as extras.

What the results show is that the current incentive scheme is much more successful in achieving some of the stated objectives than others. When all the criteria are considered together, none of the subsidised films perform well. The film subsidies were initially seen by the Department of Trade and Industry primarily as a way to attract foreign direct investment, hence the focus on production spending as a key determinant of qualification for the subsidy. A secondary concern, shaped by the political imperatives of post-apartheid South Africa, are the aims of job creation and skills development, particularly for black South Africans. The cultural content and representation of cultural diversity of the films themselves is of much less concern to the DTI, as evidenced by criteria that favoured big budget foreign films, rather than smaller budget projects from emerging black film makers. 
Research on the impact of the subsidies (Collins and Snowball, 2015) demonstrated that, in terms of economic impact and the number of jobs created, the subsidy scheme can be regarded as a success. This was particularly the case for foreign productions, where every R1 of subsidy was associated with R6.65 of production expenditure. However, in terms of achieving the transformation objective, the sample of subsidised films performed much less well. The percentage of black people employed in "skilled" categories was generally low for all production types. South African productions fared best in terms of overall black employment, but this was skewed towards lower-level employment categories, such as extras and cast (Collins and Snowball, 2015).

What the current analysis demonstrates is the inherent policy tension between some of the aims of the scheme: maximising spending (QSAPE), generating employment for South Africans (total employment), skills transfer through partnerships with international companies (co-productions) and transformation (black employment and black skilled employment). Films that score best on spending criteria tend not to create many jobs for South Africans, especially black South Africans, and especially skilled jobs.

The implications of the finding are that it might be better to have more differentiated, separate policies: one of which focuses on job creation for South Africans, heavily weighted towards black employment, especially in skilled jobs; and one focused on maximising production spending from large projects, especially coproductions and foreign films. This demonstrates how the PROMETHEE method can be used to identify policy tension and manage it effectively. 


\section{Concluding Remarks}

The applicability of the PROMETHEE multi-criteria method, supported by GAIA plane visualization, has been demonstrated in this study. It has been employed to analyse the full population of completed film and television broadcast projects eligible for state subsidy in South Africa. Some clear grouping among the projects can be discerned using the relevant performance criteria articulated by South African Government bodies and agencies operating in this policy arena.

In retrospect, it should be borne in mind that the film and television productions that qualified for the subsidy are already a fairly select group. For example, in order to apply for the subsidy, local projects have to have a minimum QSAPE of R2.5m, which does exclude a significant range of smaller projects (Industry Interviews, 2012). Furthermore 'subsidy eligible' projects cannot be classed primarily as reality shows, game shows, or advertising even though these types of projects can support many jobs and substantial spending in the local economy. In terms of employment, films eligible for subsidy have to meet Broad-based black economic empowerment quotas, and thus already represent those projects with higher levels of black contributors. The director of the NFVF estimates that there a significant number of film and television projects that take place without subsidy. Accordingly, an illuminating line of future research enquiry is warranted whereby the comparative performance of projects that did qualify for subsidy is analysed with those that did not. 


\section{References}

Barnard, H. and Tuomi, K. 2008. "How demand sophistication (de-)limits economic upgrading: Comparing the film industries of South Africa and Nigeria (Nollywood)". Industry and Innovation, 15(6): 647-668.

Behzadian, M, Kazemzadeh, R.B., Albadvi, A. and Aghdasi, M. 2010. "PROMETHEE: A comprehensive literature review on methodologies and applications". European Journal of Operational Research, 200(1): 198-215.

Botha, M. 2003. "Current film policy in South Africa: The establishment of the National Film and Video Foundation of South Africa and its role in the development of a post-apartheid film industry'. Communication: South African Journal for Communication Theory and Research, 29 (1-2) : 182 - 198.

Brans, J.-P. 1982 «'L'ingénierie de la décision: Elaboration d'instruments d'aide à la décision'» in Nadeaeu, R. and Landry, M., eds., L'aide à la décision: Nature, Instruments et Perspectives d'Avenir, Québec: Presse de l'Université de Laval, 183-213. Brans, J.-P. and Mareschal, B. 1994. "The PROMCALC \& GAIA decision support system for multicriteria decision aid”. Decision Support Systems, 12(4-5): 297-310.

Brans, J.-P. and Mareschal, B. 2005. "PROMETHEE methods" in Figueira, J., Greco, S. and Ehrgott, M., eds., Multiple Criteria Decision Analysis: State of the Art Surveys, New York: Springer.

Brans, J.-P. and Vincke, P. 1985. "A preference ranking organisation method". Management Science, 31(6): 647-656.

Creative Industries Report 2008. The Creative Industries in South Africa. (PDF) South African Human Sciences Research Council (HSRC), prepared for Department of Labour, South Africa. [Online] Available: 
https://www.labour.gov.za/downloads/documents/researchdocuments/Creative\%20Industries_DoL_Report.pdf

Collins, A. and Snowball, J. 2015. "Transformation, Job Creation and Subsidies to Creative Industries: The Case of South Africa's Film and Television Sector". International Journal of Cultural Policy, 21(1): 41-59.

DTI 2008a. The South African Film and Television Production and Co-production Incentive. Department of Trade and Industry, Republic of South Africa (PDF) [Online] Available: http://www.thedti.gov.za/financial_assistance/docs/SAcoproduction2008.pdf [Accessed 10/2/2011]

DTI 2008b. Foreign Film and Television Production Incentive. Department of Trade and Industry, Republic of South Africa (PDF) [Online] Available: http://www.thedti.gov.za/financial_assistance/docs/Foreign_Film_Guidelines2008.pdf [Accessed 10/2/2011]

DTI 2011. The South African Film and Television Production and Co-production Incentive. Department of Trade and Industry, Republic of South Africa (PDF) [Online] Available: http://www.thedti.gov.za/financial_assistance/docs/SAco-production.pdf DTI 2012. Foreign Film and Television Production and Post-Production Incentive. Department of Trade and Industry, Republic of South Africa (PDF) [Online] Available: http://www.thedti.gov.za/financial_assistance/docs/Foreign_Film_Guidelines.pdf South African Reserve Bank. 2012. Online statistical query: Exchange rate data. South African Reserve Bank [Online] Available: http://www.resbank.co.za/Research/Statistics/Pages/OnlineDownloadFacility.aspx 
Flanery, P. 2009. "What National Cinema? South African Film Cultures and the Transnational". Safundi: The Journal of South African and American Studies. 10(2):239-253.

Gazley, A., Clark, G. and Sinha, A. 2011. "Understanding preferences for motion pictures". Journal of Business Research, 64:854-861.

Ghazinoory, S., Daneshmand-Mehr, M., and Azadegan, A. 2013. "Technology selection: application of the PROMETHEE in determining preferences - a real case of nanotechnology in Iran". Journal of the Operational Research Society 64(3): 884-897.

Gilliams, S., Raymaekers, D., Muys, B. and Van Orshoven, J. 2005. "Comparing multiple criteria decision methods to extend a geographical information system on afforestation". Computers and Electronics in Agriculture, 49(1): 142-158.

Gkritzali, A., Lampel, J. and Wiertz, C. 2015. "Blame it on Hollywood: The Influence of films on Paris as product location". Journal of Business Research. doi:10.1016/j.jbusres.2015.10.005 (Article in Press)

Ishizaka, A., Nemery, P. 2013. "A Multi-Criteria Group Decision Framework for Partner Grouping when sharing Facilities" Group Decision and Negotiation, 22(4): 773799

Ishizaka, A. and Nemery, P. 2011. "Selecting the best statistical distribution with PROMETHEE and GAIA”. Computers \& Industrial Engineering, 61(4): 958-969.

Kettering, J. 2012. “Dr Strangetax or: Why Pennsylvania should learn to stop worrying and just end the film tax rebate". Pitt Tax Review. 10(1):69-86.

Lampel, J. and Germain, O. 2015. "Creative industries as hubs of new organizational and business practices". Journal of Business Research. doi:10.1016/j.jbusres.2015.10.001 (Article in Press). 
MacKenzie, J. And Walls W.D. 2013. “Australian Films at the Australian Box Office: Performance, Distribution and Subsidies". Journal of Cultural Economics, 37(2): 247269.

Mareschal, B., De Smet, Y. and Nemery, P. 2008. "Rank Reversal in the PROMETHEE II Method : Some New Results”, in IEEE 2008 International Conference on Industrial Engineering and Engineering Management, Singapore,

NFVF. 2008. South African Feature Films 2000 - 2007. National Film and Video Foundation (PDF) [Online] Available: http://nfvf.co.za/documents [Accessed: 12/5/ 20121

NFVF. 2011. Box Office Report 2011. National Film and Video Foundation [Online] Available: http://nfvf.co.za/home/22/files/R11.Box_Office_Report_T3-2011.pdf

NFVF. 2013. South African Film Industry Economic Baseline Study. National Film and Video Foundation [Online] Available:

http://nfvf.co.za/home/22/files/Baseline\%20study.pdf

NFVF website. 2013. National Film and Video Foundation [Online] Available:

http://nfvf.co.za/home/

Quarterly Labour Force Survey. 2013. Quarter 1, 2013. Statistics South Africa. [Online] Available: http://www.statssa.gov.za/publications/P0211/P02111stQuarter2013.pdf

SA Census. 2011. Census in Brief. Statistics South Africa. [Online] Available: http://www.statssa.gov.za/census2011/Products/Census_2011_Census_in_brief.pdf Teti, E., Collins, A. And Sedgwick, J. 2014. “An Offer They Couldn’t Refuse (But Probably Should Have): The Ineffectiveness of Italian State Subsidies to Moviemaking" Public Money \& Management, 34(3): 181-188. 
Tofallis, C. 2008. "Selecting the best statistical distribution using multiple criteria". Computers \& Industrial Engineering, 54(3): 690-694.

Townley, B., Beech, N., and McKinlay, A. 2009. "Managing the creative industries: Managing the motley crew". Human Relations 62(7): 939-962.

Tuomi, K. 2007. "Organisational shifts in the feature film industry: Implications for South Africa”. Transformation, 63: 68-91.

Towse, R. 2011. "Creative Industries”, in A Handbook of Cultural Economics, Towse, R. (Ed). Edward Elgar, Cheltenham. pp125-132.

United Nations Human Development Report. 2011. Sustainability and Equity: A Better Future for All [Online] Available:

http://hdr.undp.org/sites/default/files/reports/271/hdr_2011_en_complete.pdf

Vazques-Maguirre, M. and Hartmann, A. 2013. "Nonmarket strategies of media enterprises in the Mexican television industry". Journal of Business Research. 66: 17431749.

Vincenti, F. and Boccardelli, P. 2015. "Career diversity and project performance in the Italian television industry". Journal of Business Research. doi:10.1016/j.jbusres.2015.10.007 (Article in Press) 